\title{
Study of utilization three varieties of mango and concentration of apple vinegar towards physicochemical characteristics of mango chutney
}

Muhammad Husaini 1), Elfi Anis Saati 2), and Desiana Nuriza Putri 2)*

1) Student of food science and technology department, Agriculture and Animal Science Faculty, Muhammadiyah University of Malang, Indonesia

2) Food science and technology department, Agriculture and Animal Science Faculty, Muhammadiyah University of Malang, Indonesia

*Corresponding author email : dndesiana.nuriza@gmail.com

\begin{abstract}
Chutney is a native Indian processed product, made from cuts of fruits or vegetables and nuts cooked in a sweet, sour and spice mixture. The quality requirements of chutney are influenced by the use of raw materials, herbs and spices. The purpose of this study was to determine the response of three varieties of mango and its interaction with concentration of apple vinegar towards physicochemical characteristics of mango chutney. The experimental design of this study used a nested design with two factors. The first factor was three varieties of mango consisting of podang mango, gadung, and kweni and the second factor was the concentration of apple vinegar (5\%: 10\%: 15\%).Parameters analyzed were moisture content, ash content, vitamin $\mathrm{C}$, total soluble solids, total titrated acids, pH, crude fiber, antioxidant activity, color intensity, topicality and hedonic test (flavor, aroma, and appearance). The study showed that differences in mango varieties and apple vinegar concentration did not interact with moisture content, ash content, total soluble solids, total titrated acids, vitamin C, crude fiber, antioxidant activity, $\mathrm{pH}$, color intensity, topicality and hedonic test. The differences in mango varieties significantly affected on water content, color intensity ( $\mathrm{L}$ and $\mathrm{a}^{+}$), topicality, and hedonic test, whereas the difference of apple vinegar concentration had no significant effect on ash content, $\mathrm{pH}$, total soluble solids, total titrated acids, vitamin $\mathrm{C}$, crude fiber, and antioxidant activity. The optimum composition based on De Garmo test chutney made from gadung mango and 5\% apple vinegar (G2C1) with moisture content 23,50 \%, ash content 3,15\% vitamin C 0,10\%, total titrated acid $0,75 \%$, crude fiber 7,05\%, total soluble solids $4,60{ }^{\circ}$ brix, ph 4,31\%, antioxidant activity $93,67 \%$, colour intensity: lightness (L) 36,13, redness ( $\mathrm{a}^{+}$) 4,67 andyellowness $\left(\mathrm{b}^{+}\right)$10,00, Topicality $10,67 \mathrm{~cm}$, andhedonic test : appearence $2,13 \%$, aroma $3,30 \%$ andflavor $2,97 \%$.
\end{abstract}

Keywords: chutney, mango, apple vinegar

\section{Introduction}

Indonesia has various types of horticultural products that potential to be developed as food. Mango (Mangifera indica L.) has the prospect to become a superior diversification product which is supported from the productivity is quite abundant. Based on data from the Ministry of Agriculture in 2014, mango fruit ranks second to national production contribution after banana fruit with total production reached 2,431,330 tons. East Java ranks first with a percentage of 37.95\%. The mangoes of Podang, Kweni, and Gadung are among the most common varieties and they are the original mango varieties from Indonesia. The varieties are very popular, especially because the uniqueness of the taste which is slightly acidic so it is suitable for using as raw materials processed products. In addition, the appeal of mango varieties is a 
fairly good nutritional content, especially vitamin C. Vitamin C is one of the nutrients that play an important role as an antioxidant because it is effective to overcome free radicals that can damage cells or tissues. According to Yuniarti et al. (2001), the vitamin C content of Podang mango is $20.99 \mathrm{mg} / 100 \mathrm{~g}$, mango kweni $15,88 \mathrm{mg} / 100 \mathrm{~g}$ (Karinda et al., 2013) and mango gadung 13,00 mg / $100 \mathrm{~g}$ (Laroussihe, 2011).

Mango is generally processed into processed products such as juices, sweets, pickles, and dodol. Chutney is a processed product of jam made from cuts of fruits or vegetables and beans cooked in mixes, acids, and spices. The quality of chutney products as well as fruit jam can be known based on the gel formation (thickness) which is influenced by the important substance espesially the acid content. Acetic acid or vinegar is a type of acid used in the manufacture of chutney. According to Winarno et al. (1984), besides being an acid preservative is also used as a flavor enhancer, reduces sweetness, improves colloidal properties, and also improves the texture of the jam. Based on the above description it is necessary to research about the amount of acetic acid concentration added to the manufacture of mango chutney in order to obtain mango chutney with physicochemical and organoleptic qualities according to the standard. This is the basic reason for the authors to give the title of this study that is "Study of the Utilization of Three Varieties of Mango and Concentration of Apple Vinegar on the Quality of Chemical Physiology of Mango Chutney".

\section{Materials and Methods}

Materials

The materials used in this research are mangoes with varieties Podang, kweni, and gadung with medium size and maturity level of 90-95\% which is characterized by its color evenly yellow and apple vinegar alfito brand while the supporting material is onion white, ginger, cayenne pepper, sugar, iodine salt, cumin, aniseed, cinnamon, all the ingredients are found in Gadang market in Malang city.

Research methods

This research method using nested pattern design with 2 factors. Factor I is the difference of varieties of mango fruit with 3 levels in this case there are 3 varieties used are mango podang, mango gadung, mango kweni and factor II that is the concentration of apple vinegar with 3 levels of concentration $(5 \%, 10 \%, 15 \%) 9$ treatment combinations were analyzed by 3 replications. Data of physical and chemical observation using analysis of variance or Analysis of variance (ANOVA) to know influence of treatment. Furthermore, if the effect is then continued with the test duncan's level $\alpha=5 \%$ 


\section{Chutney Parameters}

The observation parameters included physical and chemical test of mango chutney with different varieties of mango and vinegar concentration in chemical test are water content analysis, ash content, vitamin $\mathrm{C}$ content, total dissolved solids, total titrated acids, crude fiber content, acidity $(\mathrm{pH})$, and Fission tests include measurements of color intensity, and organoleptic for flavor, aroma and appearance.

\section{Results and Discussion}

Water Content

Treatment of mango varieties difference showed a significant effect and apple vinegar concentration of $5 \%, 10 \%, 15 \%$ in mango varieties did not show interaction on water content of mango chutney. Table 1 shows average water content ranges from $19.21 \%$ - $22.86 \%$. The difference of water content due to the difference of moisture content of each mango varieties used, according with Antarlina (2013) mango podang varieties have $86.10 \%$ water content, mango gadung $80,10 \%$ and mango kweni equal to $74,49 \%$.

Table 1. Mean water content of Chutney using different mangoes varieties

\begin{tabular}{lcc}
\hline & Varieties & Water content (\%) \\
\hline Podang & $19,21 \mathrm{a}$ \\
Gadung & $22,86 \mathrm{c}$ \\
Kweni & $20,86 \mathrm{~b}$ \\
\hline
\end{tabular}

Different letters in each parameter are significantly different $(\mathrm{P} \leq 0.05)$.

\section{Ash Content}

Mangoes varieties showed non significant effect on ash content of Chutney and vinegar concentration $(5 \%, 10 \%, 15 \%)$ in mango varieties applied to chutney product did not show interaction on mango chutney. The average ash content of chutney with different varieties of mango and concentration of apple vinegar can be seen in Figure 1. Figure 1 shows that the highest content of ash content obtained from the treatment of podang mango varieties and 5\% vinegar concentration, and for the lowest ash content obtained from the treatment of varieties of mango gadung and $5 \%$ vinegar concentration $3.15 \%$. Based on data, it can be concluded that the chutney ash content has been in accordance with the Indian National Standard. The ash content by default is a maximum of $5.0 \%$ for chutney products (IS: 3500 1966) / (UDC-66.58.634.441). The ash content on mango chutney products with different mango varietes and vinegar concentration have different content but statistically it is not significantly different. 


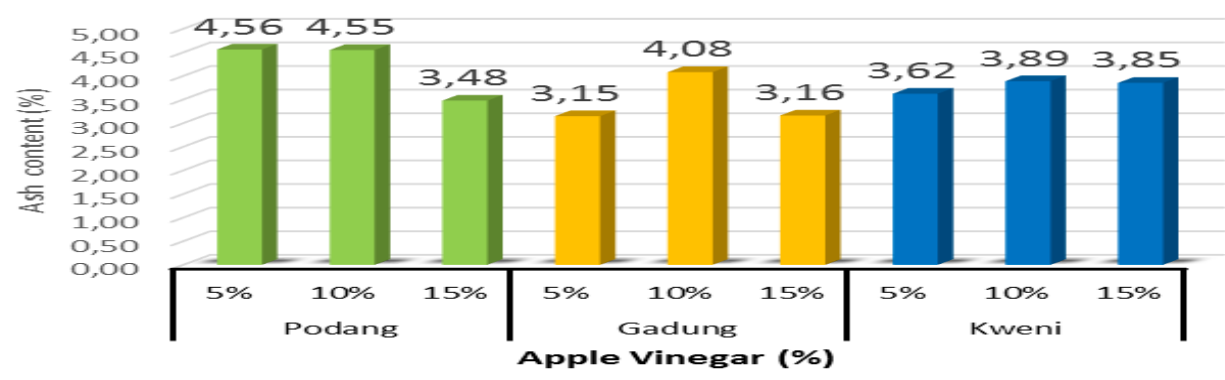

Figure 1. Ash content of chutney with using different mangoes varietes and vinegar concentration.

Vitamin C Content

Using difference of mango vareietas showed significant effect on vitamin $\mathrm{C}$ and difference apple vinegar concentration $(5 \%, 10 \%$, and $15 \%)$ in mango varieties did not show interaction with vitamin $\mathrm{C}$ content, ash content on mango chutney using mango varieties difference and concentration of apple vinegar can be seen in Figure 2.

Figure 2 shows that levels of vitamin $\mathrm{C}$ is relatively high in the treatment of mango podang and $10 \%$ of apple vinegar equal to $0.11 \%$, although gadung varietes and $10 \%$ of vinegar equal to $0.11 \%$. Vitamin $\mathrm{C}$ content on product is lower than on mango as raw materials due to cooking process. According Winarno (2008 vitamin C is easily oxidized or easily damaged due to the heat.

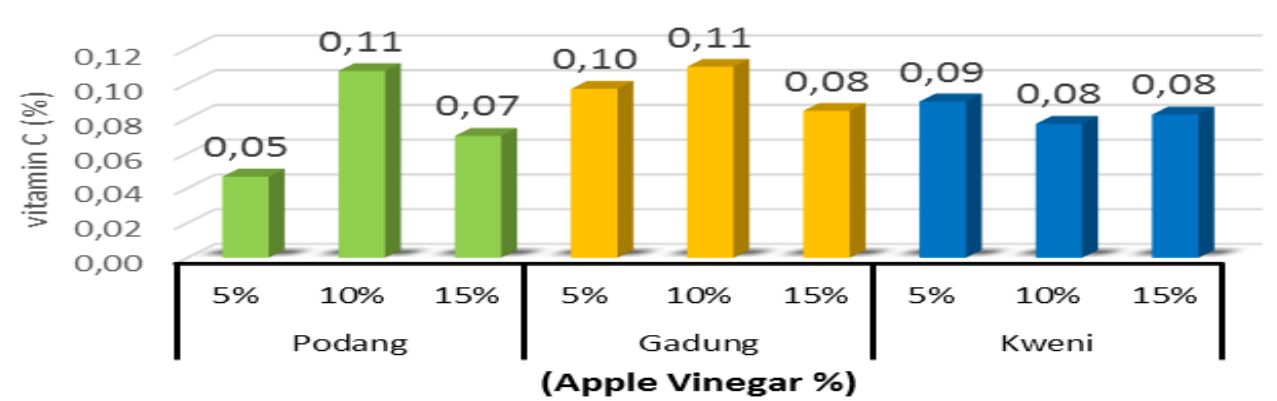

Figure 2. Vitamin C content of chutney with using different mangoes varietes and vinegar concentration.

Total soluble solids

Treatment of mango varieties difference showed no significant effect on total soluble solids of chutney and apple vinegar concentration (5\%,10\%, and $15 \%)$ in mango verietas did not show interaction on total soluble solids of mango chutney. Figure 3 shows that the total dissolved solid is relatively high on the treatment of mango podang with $15 \%$ apple vinegar concentration equal to $6.7 \%$; mango gadung with $10 \%$ vinegar concentration equal to $6.0 \%$; mango kweni with $5 \%$ apple vinegar 
concentration equal to $5.2 \%$. The treatment which has the lowest total soluble solids content was found in the treatment of mango gadung with $5 \%$ apple vinegar concentration equal to $4.6 \%$. Differences in mango varieties and concentrations of apple vinegar showed different results but were not statistically significant.

Referring to the BPOM-RI for chutney product standard No.HK.00.05.52.4040 regarding fruit-jam (eg chutney) products in this case the applied chutney product has a total soluble solids content lower than the standard of $50 \%$ total soluble solids in $100 \mathrm{~g}$ chutney and products should have a typical flavor of mango chutney. According to Setyani and Medikasari (2008). The amount of total soluble solids in a product is influenced by varieties of raw materials, chemical composition contained and amount of sugar or other carbohydrates added in the treatment.

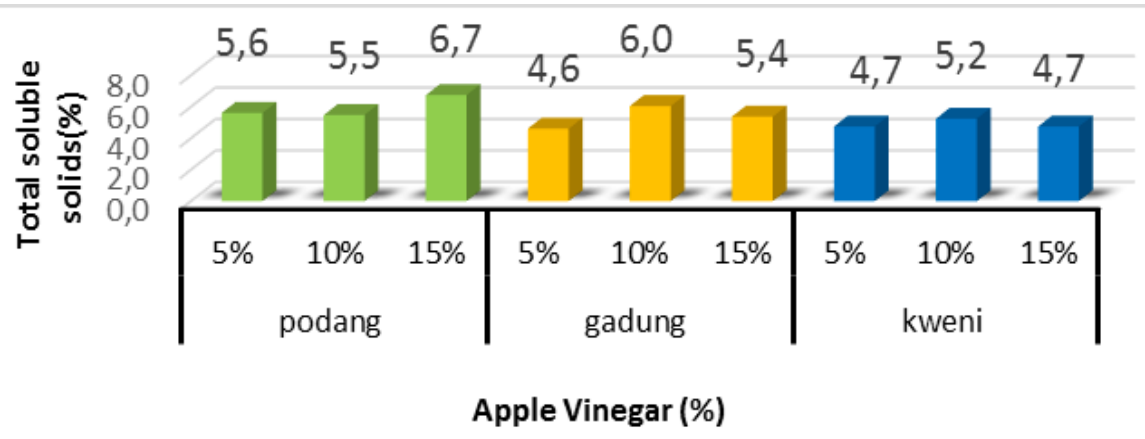

Figure 3. Total soluble solids of chutney with using different mangoes varietes and vinegar concentration

Total titrated acids

Treatment of mango vareietas difference showed no significant effect on total titrated acids of mango chutney and apple vinegar concentration $(5 \%, 10 \%$, and 15\%) in mango verietas did not show interaction with mango chutney. Figure 4 shows that the total titrated acids is relatively high on treatment of mango podang chutney with $15 \%$ apple vinegar concentration equal to $0.89 \%$, mango gadung with $5 \%$ apple vinegar concentration equal to $0.75 \%$, and mango kweni with concentration of vinegar apple $10 \%$ equal to $0.87 \%$, and the treatment with the lowest total tertitrasi acid found in the treatment of mango gadung with $15 \%$ apple vinegar concentration equal to $0.71 \%$. The total acid processessed by mango chutney with different concentrations of apple vinegar showed a higher yield compared to the chutney products circulated in the market which have a total acid content equal to $0.47 \%$. The difference between mango varieties and apple vinegar concentration shows different results but statistically not significantly different. 
The concentration of vinegar added to theprocess may trigger a rise in the total acid content of the product which according to Jhonstonet (2004) states that the use of apple vinegar in processed can add a total acid content to the product to $4.53 \%$ and may decrease the $\mathrm{pH}$. As well as other factors that resulted in a decrease in total acid content in the product caused by high temperature at cooking time, ie temperature $80 \mathrm{oC}$ for 30 minutes, With the application of temperature $80 \mathrm{oC}$ for 30 minutes. The acids contained in the fruit of mango and vinegar are added to the oxidation caused by the heat that occurs continuously.

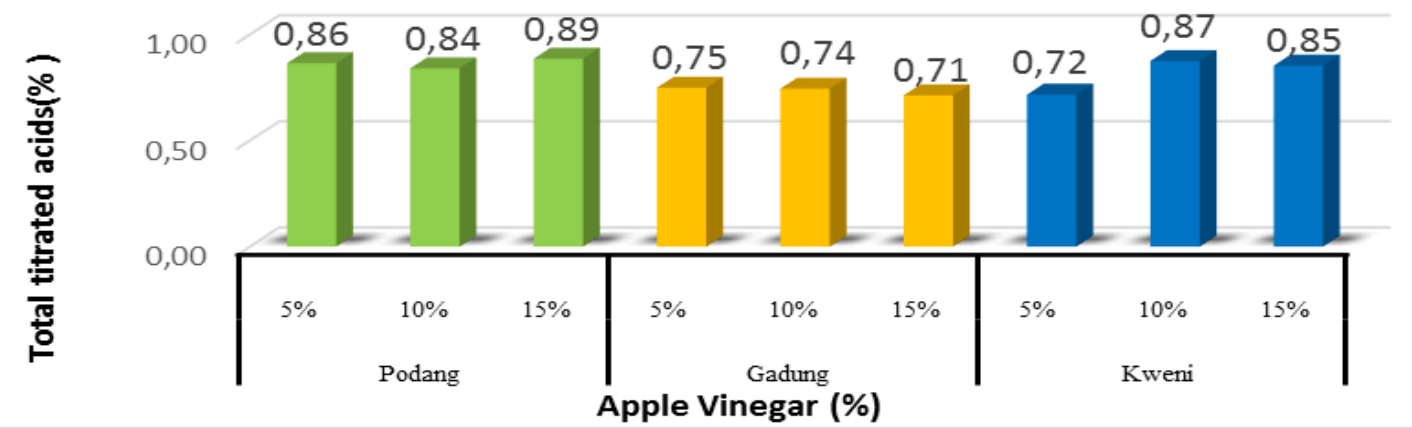

Figure 4. Total titrated acids of chutney with using different mangoes varietes and vinegar concentration

Crude fiber content

Differences in mango varieties showed no significant effect on crude fiber content of mango chutney and apple vinegar concentration (5\%,10\%, and $15 \%)$ in mango varieties did not show interaction with crude fiber of mango chutney. Figure 5 shows that different types of mango varieties and concentrations of apple vinegar have different values but not statistically significant different. The crude fibervlevel of each treatment can be due to the different types of mango verietas used in this study. This is because the crude fiber in different materials differ depending on the variety of mango used. Based on the result, comparison of crude fiber content of mango chutney with different concentration $(5 \%, 10 \%, 15 \%)$ of vinegar with chutney circulating in the market, it was concluded that the crude fiber content of mango chutney with different vinegar concentrations had a lower crude fiber content than the crude mangrove chutney fiber in the market at 9.43\%. High levels of crude fiber in chutney products that circulated in the market can be caused by the difference in the composition of raw materials used. 


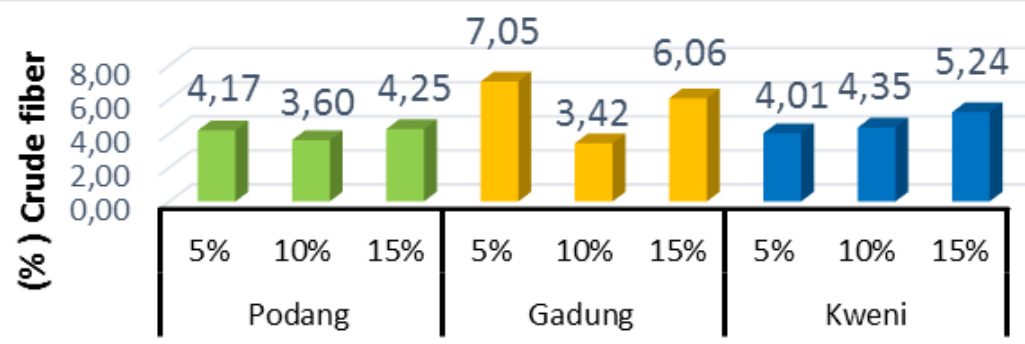

Apple Vinegar (\%)

Figure 5. Crude fiber content of chutney with using different mangoes varietes and vinegar concentration

$\mathrm{pH}$

Treatment Differences in mango varieties did not show a significant effect on mango chutney and the apple vinegar concentrations (5\%, 10\%, and 15\%) inmango varieties showed no interaction in the manufacture of chutney products. Figure 6 shows that the degree of acidity $(\mathrm{pH})$ in mango chutney is relatively the same between each treatment. This is due to the process of degradation of vinegar during the cooking process due to the nature of vinegar that is not resistant to heat. Another factor that causes low acidity or $\mathrm{pH}$ is when the process of heating some of the water has evaporated, so the $\mathrm{H}+$ ion decreases (Lilaharta 2005). The storage factor may also influence the effect of fermented acetic acid, resulting in a weak acetic acid that does not undergo perfect ionization, it may also be the reason for the increase in $\mathrm{pH}$ value of mango chutney, as well as other factors that may increase the $\mathrm{pH}$ levels of the product as a result of the reaction of hydrolysis pectin to pektat acid (Fahrizal, 2014).

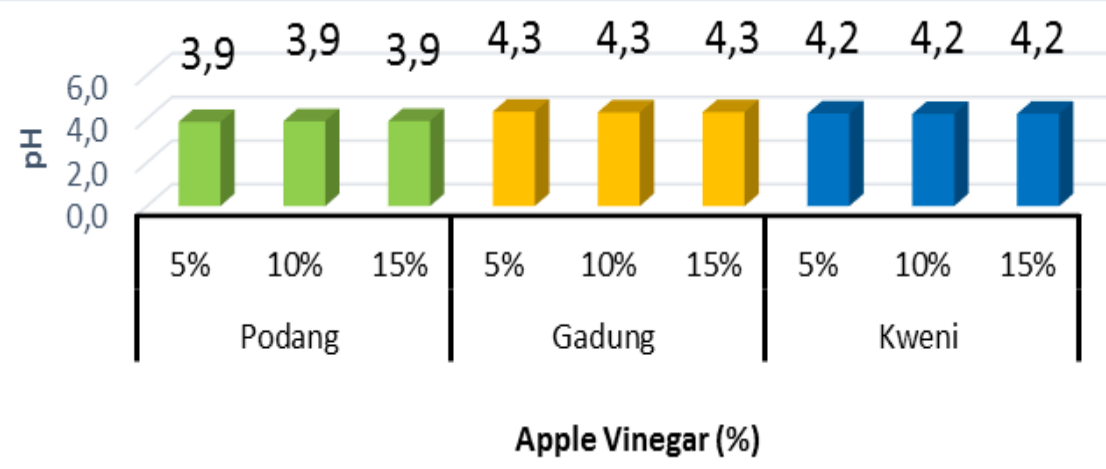

Figure 6. $\mathrm{pH}$ of chutney with using different mangoes varietes and vinegar concentration

Antioxidant activity

Differences in mango varieties showed non significant influence on mango chutney and different apple vinegar concentrations (5\%,10\% and 15\%) in mango 
varieties did not show interaction on antioxidant activity in mango chutney. Figure 7 shows that the value of antioxidant activity is relatively high. The high activity of antioxidant in mango chutney product is contributed by the supporting material used in the product where the use of spices in the form of fennel which have Aldehid and Phenol compounds, Cinnamon having Sinamaldehid, Cumin which have Aldehida compound and Phenol compound, Garlic which has Alicin compound, and Ginger that has Shogao compounds. These compounds can contribute to high antioxidant activity so as to be able to capture free radicals in DPPH solution. Free antioxidant-free radical damping occurs when unpaired electrons become paired with the presence of hydrogen donors, thus forming a stable DPPH (Yuhernita and Juniarti, 2011).

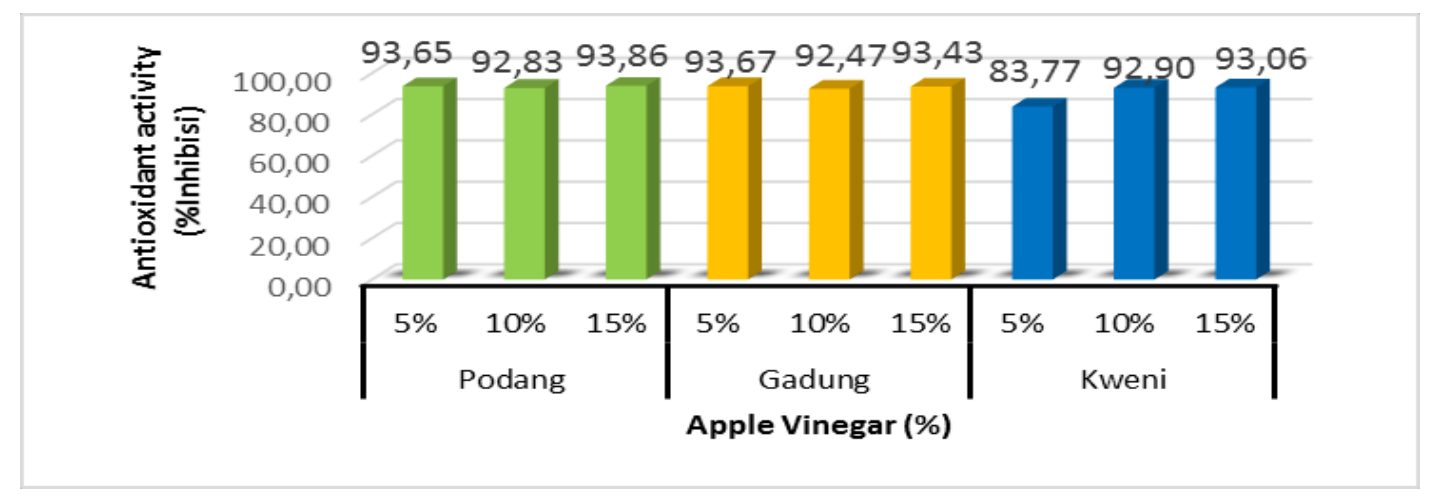

Figure 7. Antioxidant activity of chutney with using different mangoes varietes and vinegar concentration

\section{Lightness}

Treatment of mango vareietas difference showed a significant effect on mango chutney and apple vinegar concentrasion (5\%, 10\%, and 15\%) in mango verietas did not show interaction to lightness. Table 2 shows that podang variety and kweni variety showed no significant difference in brightness value (L) but gadung variety showed different notation value significantly. The degree of $\mathrm{L}$ (Lightness) in mango chutney is influenced by different carotenoid content in each variety that is used as raw material. According to USDA Nutrient Database of mango podang contains carotene compounds $8.23 \mathrm{mg} / 100 \mathrm{~g}$, mango gadung has carotene content of $5.45 \mathrm{mg} / 100 \mathrm{~g}$ and mango kweni has a carotene content of 3.03 mg / 100 g. According to Tranggono (1990), the mango has some pigment content, one of the main pigments present in the mango tissue is rubberenoids. 
Table 2. Mean lightness (L) of Chutney using different mangoes varieties

\begin{tabular}{|c|c|}
\hline Varieties & $\mathrm{L}$ \\
\hline Podang & $34,68 \mathrm{a}$ \\
\hline Gadung & $34,99 \mathrm{~b}$ \\
\hline Kweni & $37,20 \mathrm{a}$ \\
\hline
\end{tabular}

Different letters in each parameter are significantly different $(\mathrm{P} \leq 0.05)$.

Redness $(\mathrm{a}+)$

Treatment of mango vareietas difference shows a significant effect on mango chutney and apple vinegar concentrassion (5\%,10\%, and 15\%) in mango verietas did not show interaction on a + value of mango chutney. Table 3 shows that the treatment of mango varieties is significantly different. The highest value is in podang mango varieties 17.63 , followed by mango gadung 14.90 , and the last one is mango kweni 13,53. The positive a $(\mathrm{a}+)$ values indicate the sample has a degree of redness. According to Mancheix (1969), the color intensity is influenced by the pigment state and the most influential are $\mathrm{pH}$ and temperature. Using water as solvent resulted in increased yellow color due to less stable pigment conditions so that the color change from red to yellow. In this case the best treatment that produces highest a + (Redness) is the treatment of podang mango where each variety of mango has different carotenoid content. In this case it can also be concluded that from the observation of the a + (Redness) level on the mango chutney better than) in the market control sample. Where a + averages (Redness) in market samples have an a + level of $3.7 \%$.

Tabel 3. Mean redness (a) of Chutney using different mangoes varieties

\begin{tabular}{|c|c|}
\hline Varieties & $\mathrm{a}^{+}$ \\
\hline Podang & $17,63 \mathrm{c}$ \\
\hline Gadung & $14,90 \mathrm{~b}$ \\
\hline Kweni & $13,53 \mathrm{a}$ \\
\hline
\end{tabular}

Different letters in each parameter are significantly different $(\mathrm{P} \leq 0.05)$.

Yellowness $(b+)$

Treatment of mango vareietas difference did not show any significant effect on mango chutney and apple vinegar concentrassion (5\%, 10\%, and 15\%) in mango verietas showed no interaction on $b+$ value in mango chutney. This is due to the process of caramelization of sugar compounds present in mangoes that can cause a decrease in the degree of brightness of the value of $b+$ on mango chutney. The value of $b+$ is indicating a yellowish or bluish degree of a sample in which the more positive a sample having a high yellowish degree whereas the more negative the indigo $b(-b)$ indicates the sample has a high degree of blueness which this is the best treatment is the treatment of mango gadung with the concentration of vinegar $10 \%$ 


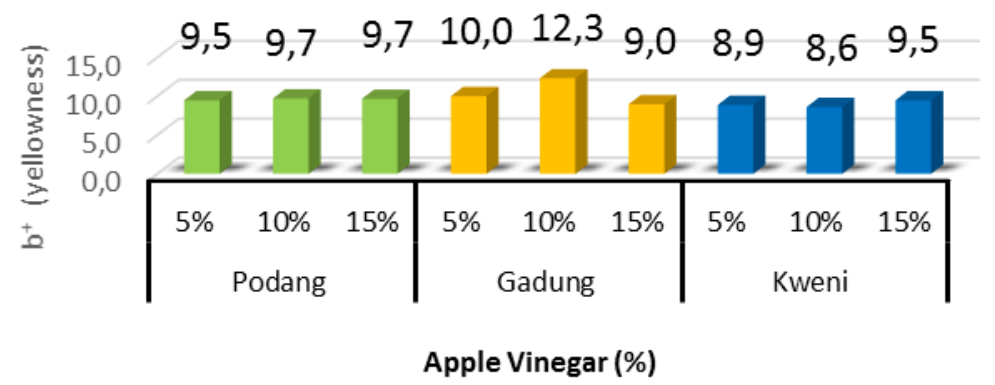

Figure 8. Yellowness $(\mathrm{b}+)$ of chutney with using different mangoes varietes and vinegar concentration

Spread capacity

Treatment of mango vareietas difference showed very significant effect on mango chutney of apple vinegar concentration and 5\%,10\%,15\% in mango verietas did not show the interaction of mast product of mango chutney. The mean result can be seen in Table 4. Based on Table 4 it was concluded that the difference of mango varieties affects the level of power of topical mango chutney product where it can be affected by different pectin content in each mango it is in tune with USDA (2003) which states that the pectin content in the fruit varies. Pectin content of podang mango ranged $0.3 \%$, Mango gadung ranged $0.3 \%$ and mango kweni ranged $0.5 \%$. According to Nurminabari (2008) the quality of pectin in food plays a role in determining the number of pectin used in gel formation.

Tabel 4. Spread capacity of Chutney using different mangoes varieties

\begin{tabular}{ll}
\hline Varieties & Spread capacity $(\mathrm{cm})$ \\
\hline Podang & $19,00 \mathrm{~b}$ \\
Gadung & $10,67 \mathrm{a}$ \\
Kweni & $19,67 \mathrm{c}$ \\
\hline
\end{tabular}

Different letters in each parameter are significantly different $(\mathrm{P} \leq 0.05)$.

Organoleptic Score

Organoleptic score of mango chutney was performed by 30 panels, where the observed parameters included the appearance, taste, and aroma of nine combination of mango chutney treatments. Organoleptic analysis shows that the appearance, textures, flavors and preferences are influenced by the raw materials in the manufacture of jams to obtain the preferred chutney by consumers. The use of mango varieties of podang, gadung, and kweni give differences to the appearance, taste and aroma. According to Yuniarti (1992) fruit volatile compounds play an important role in the formation of aroma, flavor and acid compounds contained in the fruit also affect the flavor of the product. 


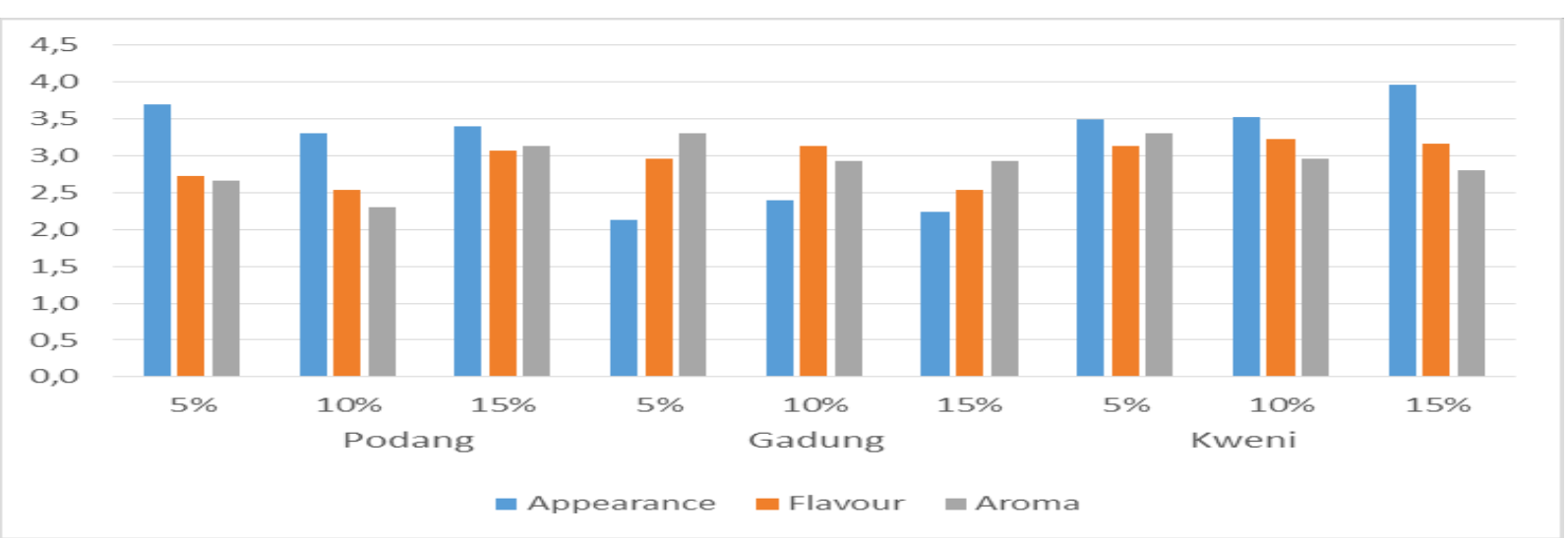

Figure 9. Organoleptic Score of chutney with using different mangoes varietes and vinegar concentration

\section{Conclusion}

Based on research study of three mango varieties and apple vinegar concentration on quality of physico chemical properties of mango chutney can be concluded that the difference of mango varieties and apple vinegar concentration did not interact on water content, ash content, vitamin $\mathrm{C}$, crude fiber, total soluble solid, total acid and hedonic test but the different treatment of mango varieties has an effect on water content, $\mathrm{pH}$, color ( $\mathrm{L}$ and $\mathrm{a}+$ ), hedonic test and the treatment of apple vinegar concentration has no effect on water content, ash content, vitamin $\mathrm{C}$, crude fiber, total dissolved solids, total titrated acids, $\mathrm{pH}$, antioxidant, smear, color $(\mathrm{L}, \mathrm{a}+\mathrm{and} \mathrm{b}+)$. The best mango chutney got treatment G2 (C1) that is mango with podang varieties with $5 \%$ apple vinegar concentration which have moisture content $23,50 \%$, ash content $3,15 \%$, vitamin $\mathrm{C} 0,10 \%$, total acid $0.75 \%$, crude fiber $7.05 \%$, total dissolved solids $4.60{ }^{\circ}$ brix, $\mathrm{pH} 4.31 \%$, antioxidant activity $93.67 \%$, color intensity: brightness (L) 36.13, redness $(\mathrm{a}+)$ 4.67, yellowing $(\mathrm{b}+)$ 10.00, and organoleptic Score $10.67(\mathrm{~cm})$.

\section{References}

Antarlina, S.S., Noor, I., Noor, D. H., Umar, S., dan Muhammad. 2003. Pemanfaatan Sumber Daya Tanaman Buah-buahan Lokal Kalimantan Selatan untuk Agroindustri. Laporan Akhir Balittra. Banjarbaru.

Fahrizal dan Fadhil, R. 2014. Kajian Fisiko Kimia dan Daya Terima Organoleptik Selai Nenas yang Menggunakan Pektin dari Limbah Kakao. Jurnal Teknologi dan Industri Pertanian.

M.H.R.Bhuiyan. 2012 J.Enviro.Sci \& Natural Resources, 5(2):67-72,2012. Pickle and Chutney Development From fresh Hog Plum (Spondias Dulcis), Depertemant of food enginering and technology, State university of banglades, Dhaka.

Nurminabari, Ina. Siti. 2008. Kajian Penambahan Sukrosa dan Pektin Terhadap Karakteristik Marmalade Jeruk Sunkist (Citrus sinensis (L) Osbeck). Universitas Pasundan. Bandung.

United States Departement Of Agriculture (USDA). National Nutrient Databese For Satandard Reference, 2008, Spesification Mango. http://Www.nal.usda.gov (diakses 4 mei 2017).

Winarno, F.G., 2002. Kimia Pangan dan Gizi. Gramedia Pustaka Utama, Jakarta.

Yuniarti, Titin. 2008. Ensiklopedia Tanaman Obat Tradisional. Yogyakarta: Media Pressindo.

Jakhetia, v, patel,R, khatri, p., pahuja, N., garg, s., pandey, A., sharman, S (2010). Cinnamon: $A$ pharmacological review, journal of advanced scientifik research, 1(2) : 19-23. 